\title{
Evaluating sulphate removal and identifying the bacterial community present in acid mine drainage treated with synthetic domestic wastewater sludge
}

\author{
MF van den Berg', M Botes ${ }^{1 *}$, E Slabbert ${ }^{2}$ and TE Cloete ${ }^{1}$ \\ Department of Microbiology, Stellenbosch University, Private Bag XI, Matieland, Stellenbosch 7600, South Africa \\ 2Central Analytical Facilities, Stellenbosch University, Private Bag XI, Matieland, Stellenbosch 7600, South Africa
}

\begin{abstract}
Domestic wastewater sludge can serve as a carbon source in the passive biotic treatment of acid mine drainage (AMD) in microbial bioreactors to create anaerobic conditions for the removal of sulphate, chemical oxygen demand (COD) and $\mathrm{pH}$ neutralization. A synthetic medium simulating domestic wastewater sludge was used in AMD treatment in a ratio of 1:1 AMD: synthetic domestic wastewater sludge (SDWWS). Sulphate and COD removal were determined at different incubation temperatures and with and without a biofilm in the bioreactors. Sulphate and COD were removed by $60.8 \%$ and $96 \%$ within $26 \mathrm{~d}$, after which a plateau was reached. Bacterial community analyses using next generation sequencing showed that Chlorobium spp. dominated at a relative percentage of $36 \%$ followed by Magnetospirillum spp. and Ornithobacterium spp. The effect of a resident biofilm in the bioreactors showed dominance of Chlorobium spp. at a relative percentage of $62 \%$ and removal of sulphates and COD at $96 \%$ and $58 \%$, respectively, after $26 \mathrm{~d}$. Incubation at $17-19^{\circ} \mathrm{C}$ reduced sulphates by only $10 \%$ and COD by $12 \%$ after $17 \mathrm{~d}$, after which a plateau was reached. Magnetospirillum spp. was the dominate organism at the end of this trial.
\end{abstract}

Keywords: acid mine drainage, domestic wastewater sludge, sulphates, COD, bacterial community

\section{INTRODUCTION}

Acid mine drainage (AMD) refers to untreated wastewater from mining activities (Geremias et al., 2003) and poses a threat to human and environmental health (Keller et al., 2005; Lee et al., 2010). AMD contains high concentrations of sulphur and heavy metals (Hughes and Gray, 2013). The formation of AMD is initiated when mining activities expose pyrite $\left(\mathrm{FeS}_{2}\right)$ to atmospheric oxygen and water that leads to the production of dissolved iron, sulphates and hydrogen ions. The formation of sulphuric acid decreases the $\mathrm{pH}$ of the water leading to the complete oxidation of pyrite to ferric iron and precipitation of ferric hydroxide (Sand et al., 2000; Costello, 2003; Druschel et al., 2004).

Various remediation methods for AMD have been investigated since the 1900s (Barnes and Romberger, 1968; Olem and Unz, 1977). These methods involve abiotic and biotic methods, which can be divided into active and passive systems (Johnson and Hallberg, 2005). Although the use of alkaline chemicals or limestone (Nairn et al., 1992) in the abiotic treatment of AMD is convenient, it is not environmentally friendly due to the formation of bulky sludge (Johnson and Hallberg, 2005). Passive biotic remediation methods rely on the use of microbial treatment systems by the once-off addition of one carbon source, such as domestic wastewater (Davison et al., 1989; Strosnider et al., 2011a and 2011b). This creates conditions that will select for specific microbial populations responsible for the removal of sulphates, organic matter content and heavy metals, as well as neutralize the $\mathrm{pH}$ of the AMD (Barton and Fauque, 2009). The main bacterial group responsible for sulphate removal during passive biotic treatment of AMD is sulphate-reducing

\footnotetext{
* To whom all correspondence should be addressed.

ธ +27218082708 / e-mail: mbr@sun.ac.za

Received 26 June 2015; accepted in revised form 23 June 2016
}

bacteria (SRB) and has been well studied (Garcia et al., 2001; Johnson and Hallberg, 2005; Pruden et al., 2006; Zhou et al., 2013). SRB oxidise organic substrates while reducing inorganic sulphate to hydrogen sulphide (LeGall and Fauque, 1988), a process known as dissimilatory sulphate removal.

Green sulphur-oxidising bacteria are involved in the removal of sulphides from the environment under anaerobic conditions. Anoxygenic photosynthesis occurs via the lightharvesting centrums (chlorosomes packed with antenna bacteriochlorophylls) situated on the inside of the cell membranes (Blankenship et al., 1995). Cellular energy is generated through anoxygenic photosynthesis, a process whereby solar energy is converted to ATP without producing oxygen, with sulphide as electron donor. Sulphides are oxidised to elemental sulphur, which is deposited externally as sulphur globules that can be removed from the wastewater system (Brune, 1995; Pott and Dahl, 1998; Frigaard and Dahl, 2008). Due to their robustness and the nature of their sulphur metabolism, anoxygenic sulphur bacteria have been widely used in wastewater treatment processes as they enable a cost-effective, low-maintenance treatment of sulphide-rich wastewater (Malik et al., 2008; Mara, 2008; Moura et al., 2009).

A passive biotic approach to AMD treatment that has not been well studied is the use of biofilms in microbial bioreactors. A biofilm can be defined as a complex community of microorganisms adhering to a surface (Characklis, 1990), forming a working unit that interacts on a physical and chemical level (Costerton et al., 1995; James et al., 1995). Specifically, COD and sulphate were removed in wastewater that had been in contact with biofilms (Lazarova and Manem, 1995; Nicolella et al., 2000; Wuertz et al., 2003; Hurse and Keller, 2004). The presence of biofilms has been described at AMD sites (Denef et al., 2011; Smucker and Vis, 2011) and may therefore play a potential role in AMD treatment. 
Domestic wastewater has a significant environmental impact due to its insufficient treatment in developing countries (Gadgil, 1998; Strosnider et al., 2011a). The passive co-treatment of AMD and domestic wastewater can meet the requirements of both treatment processes as the effluent of each consists of elements that can be used by the other (Strosnider et al., 2011b). Domestic wastewater is readily available and is therefore a convenient and cost-effective carbon source for potential treatment of AMD (Gadgil, 1998; Strosnider et al., 2011a).

It was therefore hypothesized that domestic wastewater sludge could be used as a carbon source for the treatment of AMD. The aims of this study were to determine the effect of an established biofilm and incubation temperature on the removal of sulphates and COD in AMD treatment by using synthetic media simulating domestic wastewater sludge and to investigate the bacterial community present before and after treatment.

\section{MATERIALS and METHODS}

\section{Experimental setup}

The composition of domestic wastewater sludge varies depending on the source (Al-Salem, 1987; Mohammed et al., 2012). The need therefore exists to find a standardised and representative domestic sludge composition for experimental purposes.

Therefore, in a preliminary study, synthetic domestic wastewater sludge (SDWWS) was formulated (Table 1) and a 1:1 ratio of AMD to SDWWS was determined as the optimum ratio for sulphate and COD removal (Van den Berg et al., 2016). All the components were purchased from Sigma-Aldrich (Pty) Ltd., Aston Manor, South Africa.

The following methodology was used for each trial. Medical drip bags (1 L) (Stelmed, Stellenbosch, South Africa) served as bioreactors. AMD was sampled from the Inyanda Return Water Dam at the Inyanda Coal Mine located near Emalahleni (née Witbank) in the Mpumalanga Province, South Africa, and couriered overnight in $5 \mathrm{~L}$ plastic containers before each trial and stored at room temperature $\left(20-21^{\circ} \mathrm{C}\right)$ until use. AMD and SDWWS media were added to sterile saline medical drip bags in a 1:1 ratio to a final volume of $900 \mathrm{~mL}$ in triplicate. Two different control bioreactors were included in triplicate: one control bioreactor consisting of $1: 1 \mathrm{dH}_{2} \mathrm{O}$ to AMD mixture and a medium control bioreactor consisting of a 1:1 SDWWS: $\mathrm{dH}_{2} \mathrm{O}$ mixture. Domestic wastewater sludge, collected from the anaerobic digester tank at the Pniel wastewater treatment plant (Pniel, Western Cape, South Africa) before each trial, served as an inoculum and $10 \mathrm{~mL}$ was added to the trial bioreactors before incubation. All bioreactors were incubated in a dimlylit environment for the trial period. The $\mathrm{pH}$ was measured at the initiation of each trial and the $\mathrm{pH}$ adjusted to 7.5 by using $0.5 \mathrm{M} \mathrm{NaOH}$ (Sigma-Aldrich) or $0.5 \mathrm{M} \mathrm{HCl}$ (Sigma-Aldrich) if needed, and using the PCTestr 35 Multi-Parameter digital $\mathrm{pH}$ meter (Lasec SA, South Africa). The ambient temperature was monitored twice daily with the Pocket Thermometer MT605 hand-held thermometer (Allen Instruments, Cape Town, South Africa). For sampling, $5 \mathrm{~mL}$ of the liquid contents from each bioreactor were extracted by using a sterile syringe and needle. The sulphate concentration and total chemical oxygen demand (COD) of extracted samples were measured using the Merck Spectroquant Pharo 300 and cell test kits $(4564 ; 14541)$ according to the respective protocols.

\section{The treatment of AMD with SDWWS (30 d trial)}

The bioreactors were incubated at $25^{\circ} \mathrm{C}$. The liquid samples from each bioreactor were extracted before incubation and after

\begin{tabular}{|c|c|}
\hline \multicolumn{2}{|c|}{$\begin{array}{c}\text { TABLE 1 } \\
\text { Composition of the media used as synthetic domestic waste- } \\
\text { water sludge }\end{array}$} \\
\hline Component & Mass (mg $\cdot \mathbf{L}^{-1}$ ) \\
\hline Meat extract & 2182 \\
\hline Vegetable extract & 218 \\
\hline $\mathrm{NaCl}$ & 72.7 \\
\hline $\mathrm{MgSO}_{4}$ & 182 \\
\hline $\mathrm{KH}_{2} \mathrm{PO}_{4}$ & 145 \\
\hline $\mathrm{FeSO}_{4}$ & 36 \\
\hline
\end{tabular}

every 3 days during the trial for sulphate and COD analysis until sulphate removal reached a plateau. From here on this trial will be referred to as the ' $30 \mathrm{~d}$ trial'.

\section{The treatment of AMD with SDWWS in bioreactors containing a biofilm ( $30 \mathrm{~d}$ biofilm trial)}

The effect of biofilm formation in the bioreactors on AMD treatment was determined thereafter by applying the same conditions as the above experiment for $30 \mathrm{~d}$. The liquid content of the bioreactors was discarded after the $30 \mathrm{~d}$ incubation period and replaced with fresh AMD and SDWWS media in a 1:1 ratio. The bioreactors were then again incubated for a period of $30 \mathrm{~d}$. From here on this trial will be referred to as the ' $30 \mathrm{~d}$ biofilm trial'.

A white precipitate formed at the top of the bioreactors during the trials. One bioreactor was emptied and the white substance scraped off with a sterile blade. Thereafter the sampled precipitate was inserted into a sterile Eppindorf tube and sent to the Council for Scientific and Industrial Research (CSIR) in Stellenbosch for analyses using the ICP OES method.

\section{The treatment of AMD with SDWWS at a reduced incubation temperature}

The bioreactors were incubated between 17 and $19^{\circ} \mathrm{C}$ to simulate environmental conditions at a lower temperature. The COD and sulphate concentrations were monitored before incubation and every 3 days during the trial until a plateau was reached.

\section{Determining the microbial diversity present in the bioreactors before and after the AMD treatment trial period using next generation sequencing}

One bioreactor from each mentioned trial was well shaken and a sample was extracted before and after incubation (30 d) using a sterile needle and syringe. A total of $4 \mathrm{~mL}$ from the respective samples were centrifuged $\left(6000 \mathrm{~g}, 5 \mathrm{~min}, 18^{\circ} \mathrm{C}\right)$, the supernatant was discarded and the resulting pellets were re-suspended in 200 $\mu \mathrm{L} \mathrm{dH_{2 }} 0$. The resulting $200 \mu \mathrm{L}$ solution was exposed to a layer of activated carbon in a ratio of $1: 10 \mathrm{v} / \mathrm{v}$ (Jacobi Carbons, Germany) for $2 \mathrm{~h}$ at room temperature $\left(23^{\circ} \mathrm{C}\right)$ in order to reduce the amount of PCR inhibitors sufficiently to allow for PCR amplification (Abolmaaty et al., 2007). The samples were centrifuged and the resulting pellets re-suspended in $200 \mu \mathrm{L} \mathrm{dH}_{2} 0$. The $\mathrm{ZR}$ Soil Microbe DNA Miniprep Kit (Zymo Research Corporation, USA.) was then used following the recommended protocol. The extracted DNA was sent to the Central Analytical Facility (CAF, Stellenbosch) for amplicon library preparation and next generation sequencing (NGS) process. The variable region V3 to V4 of the bacterial 16S rRNA genes were targeted for PCR amplification using Fusion primers (Huse et al., 2008) to create amplicon libraries (IDT, USA). Barcodes were used to allow multiplexing 
during sequencing (Ion Express barcodes, IDT). After equimolar pooling of amplicons and library templating, sequencing on the 318 chip was performed using the OT2 and Ion Torrent PGM systems (Thermo Fisher, USA).

The sequencing data obtained were analysed using Mothur version 1.33.3 (Schloss et al., 2009). The BAM file format was converted to standard flowgram format (sff), followed by the sort and trimming of the barcodes and adaptors. Sequences with quality scores over 20 and length over $250 \mathrm{bp}$ were retained. Sequences were aligned against the ARB-SLIVA reference alignment. Sequences were clustering at $97 \%$ sequence similarity and chimeric sequences identified and removed using Uchime. Sequence clusters were classified using the RDP v14 reference taxonomy.

\section{RESULTS and DISCUSSION}

\section{The treatment of AMD with SDWWS (30 d trial)}

The bioreactors showed an average removal of $674.3 \mathrm{mg}-\mathrm{SO}_{4} \cdot \mathrm{L}^{-1}$ sulphate (96\%) (Fig. 1) and $827 \mathrm{mg}-\mathrm{COD} \cdot \mathrm{L}^{-1}$ (60.8\%) (Fig. 2), after which total removal was reached after $26 \mathrm{~d}$ for both. The highest removal of sulphates and COD during the trial period took place during the first 3 days with an average removal of $120 \mathrm{mg} \cdot \mathrm{L}^{-1} \cdot \mathrm{d}^{-1}$ and $109 \mathrm{mg} \cdot \mathrm{L}^{-1} \cdot \mathrm{d}^{-1}$, respectively, and $56 \mathrm{mg} \cdot \mathrm{L}^{-1} \cdot \mathrm{d}^{-1}$ and $45 \mathrm{mg} \cdot \mathrm{L}^{-1} \cdot \mathrm{d}^{-1}$ between Days 3 and 7 , after which it gradually decreased. The AMD: $\mathrm{dH}_{2} \mathrm{O}$ control showed virtually no change in sulphate levels and a $106 \mathrm{mg}-\mathrm{COD} \cdot \mathrm{L}^{-1}(61 \%)$ increase, whereas the SDWWS: $\mathrm{dH}_{2} \mathrm{O}$ control had virtually no change in either sulphate or COD levels. The liquid contents in the bioreactors changed from transparent to dark green during the $30 \mathrm{~d}$ incubation period and a white precipitate was seen at the top of the bioreactors (Fig. 3). The main components of the precipitated substance were sulphur $\left(207 \mathrm{mg} \cdot \mathrm{L}^{-1}\right)$ and organic carbon (229 mg. $\mathrm{L}^{-1}$ ). This indicated the possible presence of Chlorobium spp. in the bioreactors as these species precipitate sulphur in the form of globules (Pott and Dahl, 1998).

Vieira and co-workers (2016) treated synthetic AMD in a 6-L bench-scale reactor at $30^{\circ} \mathrm{C}$ with ethanol as an energy source and used sludge obtained from an up-flow anaerobic sludge bed reactor treating slaughterhouse waste as an inoculum. Sulphate and COD removal were $38.5 \%$ and $91.7 \%$, respectively, at an initial $\mathrm{pH}$ of 7 , and increased to $52.2 \%$ and $99 \%$ at an initial $\mathrm{pH}$ of 4 . These processes occurred within $10 \mathrm{~h}$.

Treatment at $30^{\circ} \mathrm{C}$ was therefore ideal for sulphate removal; however, a possible reason for the shorter treatment time is the easier accessibility of the energy source for sulphate-reducing bacteria than synthetic wastewater sludge. The uneconomical implications of the treatment at $30^{\circ} \mathrm{C}$ should be kept in mind as external temperatures vary and heating of the bioreactor may become expensive and not viable.

\section{The treatment of AMD with SDWWS in bioreactors with a biofilm ( $30 \mathrm{~d}$ biofilm trial)}

Biofilm formation was observed on the inside of the bioreactors after the liquid content was discarded at the end of the $30 \mathrm{~d}$ incubation period. AMD treatment was then conducted in the same bioreactors. The sulphate and COD levels reduced by an average of $905.33 \mathrm{mg}-\mathrm{SO}_{4} \cdot \mathrm{L}^{-1}$ (96\%) (Fig. 1) and $757 \mathrm{mg}-\mathrm{COD} \cdot \mathrm{L}^{-1}$ (58\%) (Fig. 2), respectively, after $26 \mathrm{~d}$, after which a plateau was reached. The highest removal of sulphates and COD, respectively, during the trial period also took place during the first 3 days, with an average removal of $120 \mathrm{mg}-\mathrm{SO}_{4} \cdot \mathrm{L}^{-1} \cdot \mathrm{d}^{-1}$ and 190

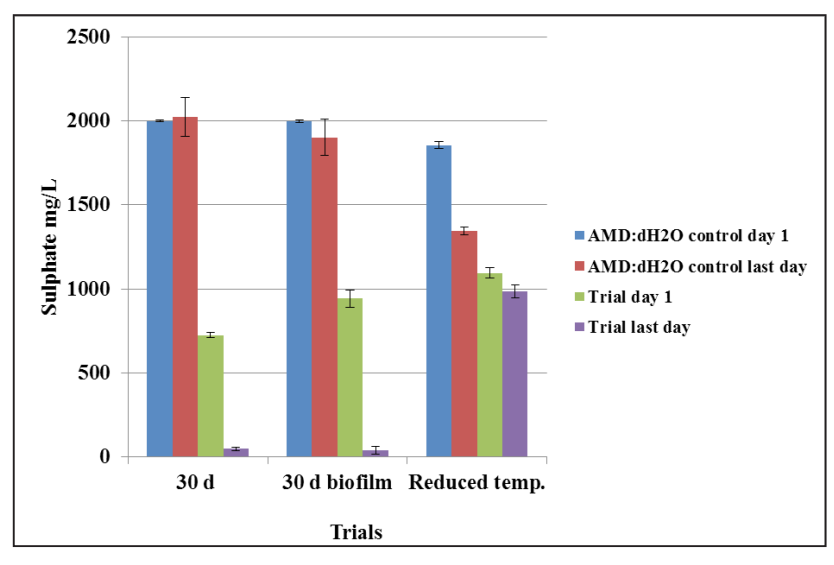

Figure 1

Sulphate concentrations of AMD treated with SDWWS and the (AMD: $\mathrm{dH}_{2} \mathrm{O}$ controls) determined on Day 1 and the last day of each respective trial

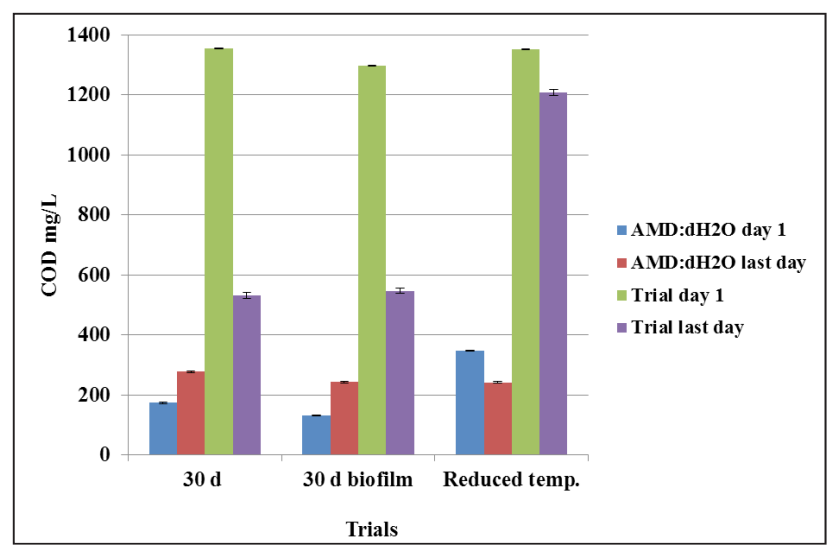

Figure 2

$C O D$ concentrations of the AMD treated with SDWWS and the (AMD:dH $\mathrm{H}_{2} \mathrm{O}$ controls) on Day 1 and the last day of each respective trial

$\mathrm{mg}-\mathrm{COD} \cdot \mathrm{L}^{-1} \cdot \mathrm{d}^{-1}$, and an average removal of $43 \mathrm{mg}-\mathrm{SO}_{4}^{-} \cdot \mathrm{L}^{-1} \cdot \mathrm{d}^{-1}$ and $96 \mathrm{mg}-\mathrm{COD} \cdot \mathrm{L}^{-1} \cdot \mathrm{d}^{-1}$ between Days 3 and 13, after which both gradually decreased. The results are therefore similar to the results of the $30 \mathrm{~d}$ trial. A possible explanation for the results in this study is that only a small percentage of the liquid content in the bioreactors was in contact with the biofilm and there was not a continuous flow of nutrients. The suspended microorganisms were therefore responsible for the sulphate removal. There was no visible difference in the colour of the liquid contents between the $30 \mathrm{~d}$ trial and this trial. Both the AMD: $\mathrm{dH}_{2} \mathrm{O}$ control and the SDWWS: $\mathrm{dH}_{2} \mathrm{O}$ control showed virtually no change in either the sulphate or the COD levels.

\section{The treatment of AMD with SDWWS at a reduced incubation temperature}

The trial conducted at $17-19^{\circ} \mathrm{C}$ resulted in an average removal of $509 \mathrm{mg}-\mathrm{SO}_{4} \cdot \mathrm{L}^{-1}(10 \%)$ (Fig. 1) and $144 \mathrm{mg}-\mathrm{COD} \cdot \mathrm{L}^{-1}$ (12\%) (Fig. 2) and reached a plateau after $17 \mathrm{~d}$. Virtually no change in sulphate and COD concentrations was found in the SDWWS: $\mathrm{dH}_{2} \mathrm{O}$ control. However, the AMD: $\mathrm{dH}_{2} \mathrm{O}$ control showed a decrease of $109.4 \mathrm{mg}-\mathrm{SO}_{4} \cdot \mathrm{L}^{-1}(27 \%)$ (Fig. 1) and $106.66 \mathrm{mg}-\mathrm{COD} \cdot \mathrm{L}^{-1}$ (30\%) (Fig. 2). Therefore, when comparing the results to the trials conducted at $25^{\circ} \mathrm{C}$, it is clear that the treatment requires higher temperatures. A study conducted by Poinapen (2012) supports the importance of incubation 
temperature. They investigated the treatment of AMD regarding sulphate removal using primary domestic sewage sludge in an upflow anaerobic sludge bed reactor at $20^{\circ} \mathrm{C}$ and $35^{\circ} \mathrm{C}$. They found a delayed start-up and a reduced COD removal in the $20^{\circ} \mathrm{C}$ reactor.

Greben et al. (2002) also emphasized the importance of incubation temperature and the reduced sulphate removal rate under conditions of lower temperatures. Greben and co-workers used anaerobic batch bioreactors to test the effect of lower temperatures and carbon source on the rate of sulphate removal. Synthetic AMD and a mixture of technical grade ethanol as carbon and energy source were used. At $\leq 15^{\circ} \mathrm{C}$ practically no sulphate removal took place whereas a bioreactor operating at $20^{\circ} \mathrm{C}$ was able to remove $7.80 \mathrm{~g} \cdot \mathrm{d}^{-1}$ sulphate.

\section{PCR and next-generation sequencing}

\section{Comparison of the dominant microbial species present at the beginning and end of each trial}

The main contributors to the microbial community composition of the respective trials at the beginning and end of the respective experimental periods were compared based on their relative abundance in the sequencing data and expressed as a percentage (Fig. 4).

With regards to the interpretation of the sequencing data obtained it should be stressed that the number of sequences obtained from each trial does not necessarily reflect the number of microbial organisms present in the particular bioreactor as the gDNA obtained was not quantified. From this point onwards this will be referred to as relative abundance percentage.

A dominance of Chlorobium spp. was detected at the end of the $30 \mathrm{~d}(35.62 \%)$ and $30 \mathrm{~d}$ biofilm trial (62.21\%) but not in the reduced incubation temperature trial. The importance of incubation temperature on the selection of bacteria has previously been stated (Madigan et al. 1997). The highest relative abundance percentage of Magnetospirillum spp. occurred in the reduced incubation temperature trial (16.58\%). This was not unexpected as Magnetospirillum spp. are microaerophilic and use iron as an electron donor (Zhu et al., 2010). This supports the general characteristic of AMD being high in heavy metal concentration (Geremias et al., 2003). The Magnetospirillum spp. abundance in the $30 \mathrm{~d}$ trial (4\%) was higher than in the $30 \mathrm{~d}$ biofilm trial (1.2\%). The lower abundance of Magnetospirillum spp. is possibly due to competition between Magnetospirillum spp. and the dominant bacterial genera, Chlorobium spp.

(Hibbing et al., 2009). Clostridium spp. was detected in all trials and has also been detected in wastewater treatment processes by Burns and co-workers (2012).

The relative abundance of Turneriella spp. found in the $30 \mathrm{~d}$ trial was $1.3 \%$, in the $30 \mathrm{~d}$ biofilm trial was $1 \%$ and in the reduced incubation temperature trial was $0.8 \%$. The abundance of Turneriella spp. detected at the beginning and end was relatively similar with abundance varying between $0.6 \%$ and $1.1 \%$. Desulfovirga spp. was present in all the trials at between $0 \%$ and $0.1 \%$ at the beginning, and between $0 \%$ and $0.5 \%$ at the end. Pseudomonas spp. was present at the beginning of all trials, at $2.25 \%$ in the case of the reduced incubation temperature trial, $3.43 \%$ at the beginning of the $30 \mathrm{~d}$ trial and $9.09 \%$ in the case of the $30 \mathrm{~d}$ biofilm trial, but was undetected at the end of all of the respective trials, except for the reduced incubation temperature trial (7.24\%) and the $30 \mathrm{~d}$ biofilm trial (0.38\%).

Azospirillum spp. was detected in the reduced incubation temperature trial (13\%) and at the beginning of the $30 \mathrm{~d}$ trial (4.7\%), despite Azospirillum spp. not being detected at the beginning of the reduced incubation temperature trial. It is possible that Azospirillum spp. was present at the beginning of the reduced incubation temperature trial but was below detectable limits.

Gordonia spp. was detected on the first day of the $30 \mathrm{~d}$ trial (2.29\%) and the $30 \mathrm{~d}$ biofilm trial (0.88\%). Elizabethkingia spp. was detected at the beginning of the reduced incubation

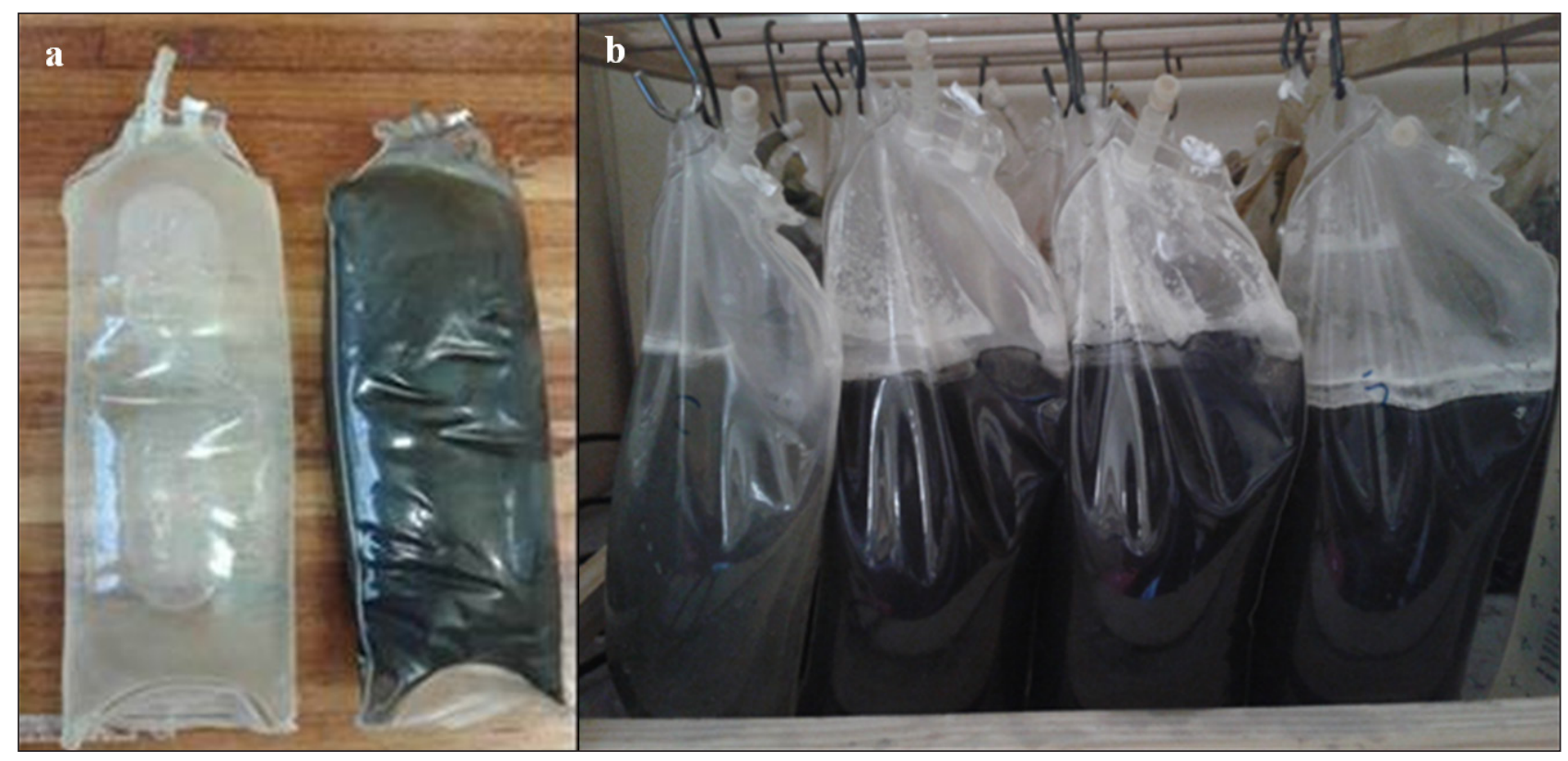

Figure 3

a) Photograph showing the colour change of the liquid contents in the bioreactors during the $30 \mathrm{~d}$ treatment trial. Left: control Right: bioreactor after the $30 \mathrm{~d}$ trial.

b) Photograph showing the white precipitate that formed in the bioreactors. 
temperature trial (7.84\%) and at the beginning of the $30 \mathrm{~d}$ biofilm trial (1.73\%). In the remainder of the trials species from this genus were undetected. In the case of all but the reduced incubation temperature trial Haliscomenobacter spp. was undetected (at a relative abundance percentage of $0.5 \%$ ) except for being detected at the beginning of the $30 \mathrm{~d}$ trial $(5.86 \%)$. At the beginning of the reduced incubation temperature trial Sulfurospirillum spp. was detected at $1.78 \%$ but was not detected at the end of the trial. At the beginning of the $30 \mathrm{~d}$ trial Sulfurospirillum spp. was undetected but at the end of this trial was detected at a relative amount of $0.57 \%$. Similarly, Sulfurospirillum spp. was detected at a relative abundance percentage of $0.19 \%$ at the end of the $30 \mathrm{~d}$ biofilm trial but was undetected at the beginning of the trial.

\section{Description of sequence analyses for each trial}

\section{Sequence analyses of the $30 \mathrm{~d}$ and $30 \mathrm{~d}$ biofilm trials}

Chlorobium spp. was dominant in the $30 \mathrm{~d}$ trial, followed by Magnetospirillum spp. and Ornithobacterium spp. (Fig. 5). Chlorobium spp. is a genus of green sulphur bacteria that occurs in dimly-lit anoxic environments (Van Gemerden and Mas, 1995). They contain bacteriochlorophyll as a light-harvesting pigment, which explains the green colour of the liquid contents of the bioreactors (Figueras et al., 1997) (Fig. 3). They are also present in domestic wastewater treatment plants (Valle et al., 2004; Hesham et al., 2011). The presence of Magnetospirillum spp. can be explained by the high concentrations of heavy metals present in AMD (Geremias et al., 2003; Zhu et al., 2010). Sulphate reducers (Desulfovirga spp.) were detected at low relative levels. These results coincide with the finding that phototrophic bacterial wastewater treatment systems offer an alternative to conventional treatment options (Almasi and Pescod, 1996). A low number of Flavobacterium spp. relative to the number of Chlorobium spp. was detected. As many phototrophic bacteria are known to produce iron-sulphur proteins (Renger, 2008), the available sulphur would likely be utilized for the production of such proteins, thereby partially removing the involved sulphur from the environment.

Bacteria also detected in the $30 \mathrm{~d}$ trial included Sphingobacteria spp., Lentisphaerales and Victivallales, Alphaproteobacteria including Caulobacteraceae spp., Rhizobiales spp., Rhodopseudomonas, Salinarimonas, Rhizobium, Rhodospirillales (Fodinicurvata and Magnetospirillum), and Epsilonproteobacteria including Campylobacterales spp., Spirochaetes spp., Firmicutes spp., and Clostridia spp. including Ruminococcaceae, Sporobacterium and Lutispora.

The $30 \mathrm{~d}$ biofilm trial had a higher presence of Chlorobium spp. when compared to the $30 \mathrm{~d}$ trial (Fig. 5). This was expected as the treatment process already indicated a selection for Chlorobium spp. In both trials, the sulphate was probably metabolically converted to sulphides by SRB, although NGS showed a low relative abundance percentage of SRB. Chlorobium spp. then oxided the sulphides to elemental sulphur and removed the sulphur from the system by depositing it externally in globules (Pott and Dahl, 1998). However, there were not large differences in the sulphate removal efficiency between the two trials. It was proposed that either the sulphate content was depleted or the conditions were not optimal after a time period for the SRB to function metabolically. Therefore the greater presence of Chlorobium spp. did not make a difference to removal efficiency.

Hurse and Keller (2004) simulated a biological sulphide removal (BSR) process by using biofilms dominated by green sulphur bacteria (GSB) in perspex vessels to remove sulphides from

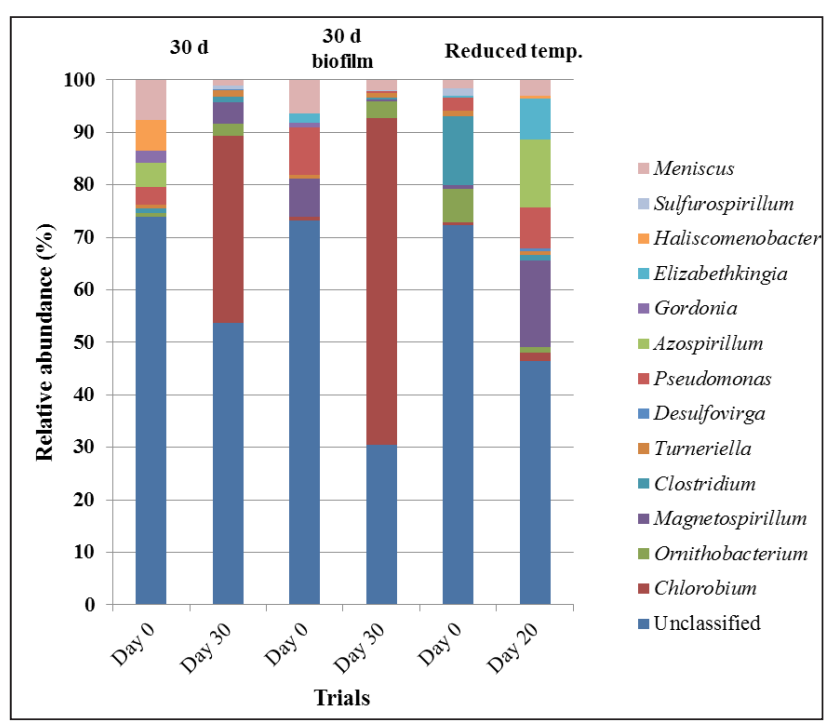

Figure 4

Relative abundance (\%) of the most abundant bacterial phyla detected, from 165 rRNA sequencing of the samples taken on the first and last day of each respective trial

wastewater. The green biofilm that developed within a week was identified by electro-micrographs as Chlorobium spp. Sulphide removal was calculated at $2.23 \mathrm{~g} \cdot \mathrm{m}^{-2} \cdot \mathrm{d}^{-1}$ at a bulk sulphide concentration of $16.5 \mathrm{mg} \cdot \mathrm{L}^{-1}$. This study was similar to the research of Hurse and Keller (2004) with regards to the use of transparent bioreactors, synthetic wastewater, an inoculum from the anaerobic digester and incubation temperature. Although the treatment did not involve irradiation it is proposed that the exposure of the bioreactors to dim light provided an optimum energy band for the selection of Chlorobium spp. However, specifically sulphides were removed from the wastewater by the Chlorobium spp. This confirms that the sulphates in the SDWWS were probably reduced to sulphides by the present SRB and that Chlorobium spp. oxidised the sulphides to elemental sulphur.

The microbial diversity of the $30 \mathrm{~d}$ biofilm trial also appeared to be higher than the $30 \mathrm{~d}$ trial, which may be attributed to the established biofilm. This included species from the Bacteroidetes division (mainly Prolixibacter), Bacteroidia including Alkaliflexus, Paludibacter and Petrimonas, Meniscus and Sphingobacteriaceae from the Sphingobacteria division, the Flavobacteria division including Ornithobacterium, Chlorobi, Lentisphaerales and Victivallales, Alphaproteobacteria including Caulobacteraceae spp., Rhodospirillales spp., Betaproteobacteria including Burkholderiales spp. and Rhodocyclales spp., Deltaproteobacteria including Desulfobacterales spp., Desulfovibrionales spp. and Geobacter, Epsilonproteobacteria divisions including Sulfurospirillum and Thioreductor, Gammaproteobacteria including Chelonobacter, Acinetobacter, Azomonas, Pseudomonas and Stenotrophomonas. The Spirochaetes spp. present included Brevinema and Turneriella and other present micro-organisms included Opitutus, Firmicutes, Clostridia spp. including Sedimentibacter, Anaerovorax, Johnsonella, Moryella, Sporobacterium, Peptococcus, Ruminococcaceae spp. and Negativicutes spp.

\section{Sequence analyses of the trial conducted at reduced incuba- tion temperatures}

The microbial analyses of the trial conducted at $17-19^{\circ} \mathrm{C}$ revealed more diversity compared to the $30 \mathrm{~d}$ trials (Figs 4 and 6). Species from the bacterial divisions Alphaproteobacteria 


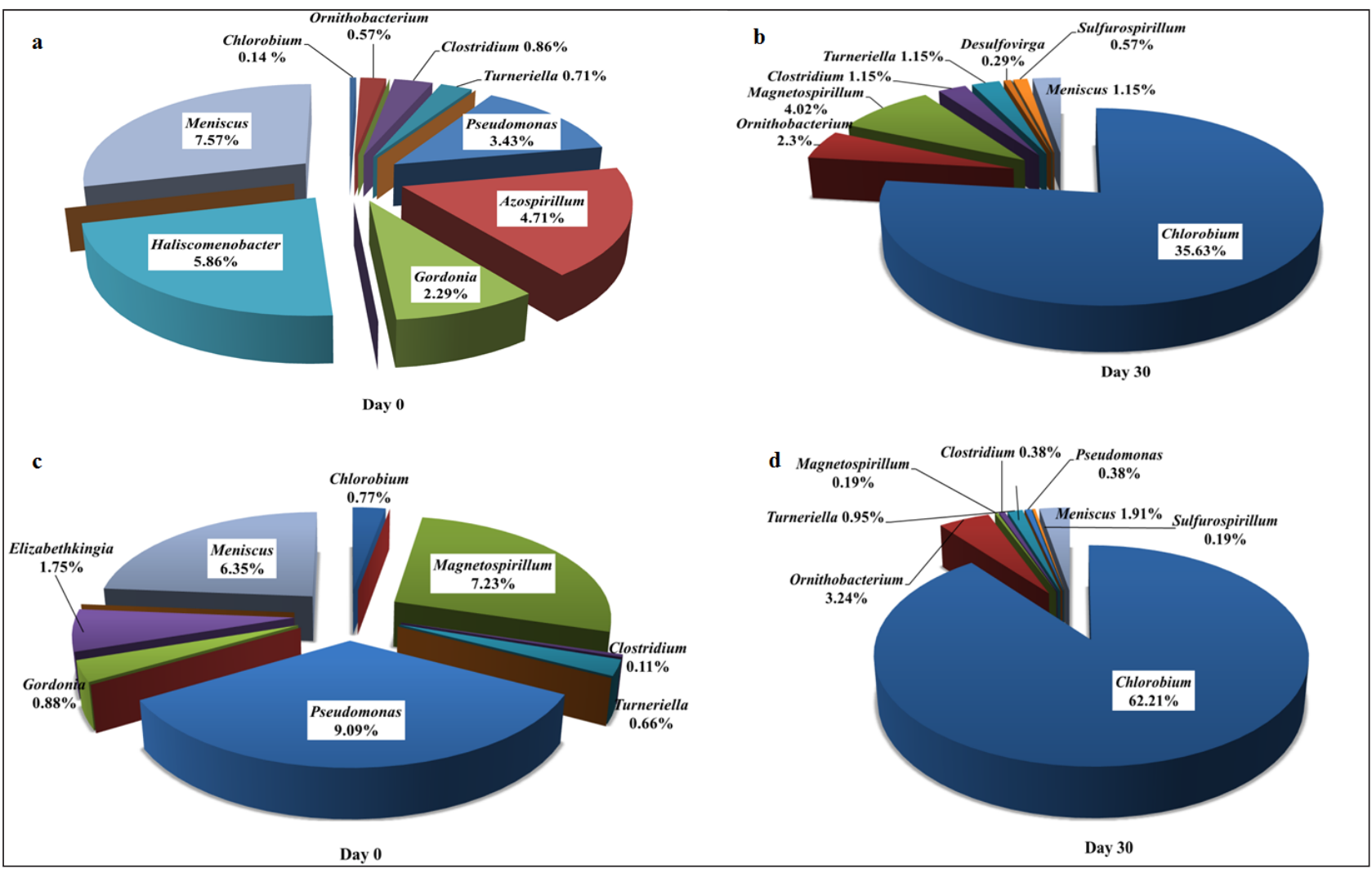

Figure 5

Sequence analysis of the $30 \mathrm{~d}$ trial on Day 0 (a) and Day 30 (b) and the $30 \mathrm{~d}$ biofilm trial on Day 0 (c) and Day 30 (d) presented as relative abundance (\%)

(Caulobacterales, Rhizobiales, Rhodobacterales, Rhodospirillales and Magnetospirillum), Betaproteobacteria (Burkholderiales and Rhodocyclales), Deltaproteobacteria (including Desulfovibrionales and Desulphuromonadales), Epsilonproteobacteria (including species from the genera Campylobacterales and Nautiliales), Gammaproteobacteria (including Enterobacteriales spp. Xanthomonadales spp., Pseudomonas spp., Spirochaetes spp, Firmicutes spp.) and Flavobacteria spp. (including Ornithobacterium spp.) were detected (Fig. 6). Chlorobium spp. was detected at $1.61 \%$ indicating that the incubation temperature was not optimum for Chlorobium spp. growth that presumably led to the low removal in sulphates and COD.

\section{CONCLUSIONS}

Treatment of AMD with synthetic domestic wastewater sludge, inoculated with sludge from an anaerobic digester, was successful in the removal of sulphates and COD in bioreactors incubated for $30 \mathrm{~d}$ at $25^{\circ} \mathrm{C}$ in a dimly-lit environment. The conditions in these bioreactors favoured the growth of a microbial community that removed sulphates and subsequently led to the relative abundance percentage of Chlorobium spp. at the end of these trials. The green colour of the liquid contents and the white precipitate consisting of sulphur found on the inside of the bioreactors after each trial confirmed the presence of Chlorobium spp. Although a higher relative abundance percentage of Chlorobium spp. was found in the $30 \mathrm{~d}$ biofilm trial, the sulphate removal efficiencies in the two trials were similar. Therefore it can be concluded that the suspended microorganisms were responsible for the sulphate removal. It was proposed that these microorganisms involved SRB that reduced sulphates to sulphides and that Chlorobium spp. oxidised the sulphides to elemental sulphur as sulphur precipitates.
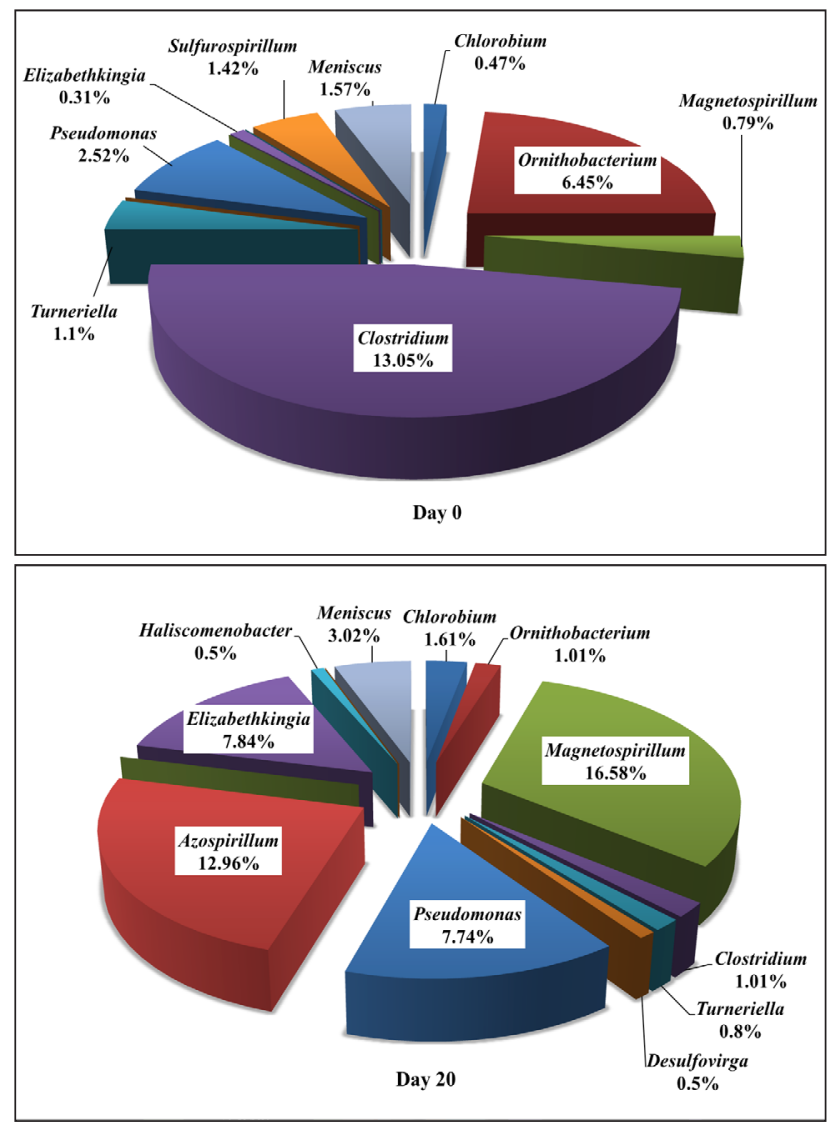

Figure 6

Sequence analysis of samples taken on Day 0 and Day 20 of the reduced incubation temperature trial presented as relative abundance (\%) 
Bioreactors incubated at $17-19^{\circ} \mathrm{C}$ showed a low removal of sulphates and COD in AMD treatment. The highest relative increase in abundance was that of Magnetospirillum spp. after $20 \mathrm{~d}$. A lower incubation temperature is therefore not optimum for microorganisms involved in sulphate and COD removal. Incubation temperature should therefore be considered when using domestic wastewater sludge for the treatment of AMD especially across different seasons.

A few microbial species were not detected at the beginning of a trial although they were detected at the end of the treatment. This emphasises the importance of perspective when dealing with next-generation sequencing technology, as also stated by Shendure and Ji (2008).

This study showed that AMD can potentially be treated with anaerobic domestic wastewater sludge when conditions are optimised to select for the microbial community involved in sulphate removal. The conditions proposed are the use of transparent bioreactors kept in a dimly-lit environment at $25^{\circ} \mathrm{C}$. Future studies will involve upscaling of the volume treated and replacement of SDWWS with fresh anaerobic domestic wastewater sludge.

\section{ACKNOWLEDGEMENTS}

The authors would like to thank Exxaro for funding.

\section{REFERENCES}

ABOLMAATY A, GU W, WITKOWSKY R and LEVIN RE (2007) The use of activated charcoal for the removal of PCR inhibitors from oyster samples. J. Microbiol. Meth. 68 (2) 349-352. http://dx.doi. org/10.1016/j.mimet.2006.09.012

ALMASI A and PESCOD MB (1996) Wastewater treatment mechanisms in anoxic stabilization ponds. Water Sci. Technol. 33 (7) 125-132. http://dx.doi.org/10.1016/0273-1223(96)00347-2

AL-SALEM SS (1987) Evaluation of the Al Samra waste stabilization pond system and its suitability for unrestricted irrigation. Paper prepared for the Land and Water Development Division, FAO, Rome.

BARNES HL and ROMBERGER SB (1968) Chemical aspects of acid mine drainage. J. Water Pollut. Control Fed. 40 (3) 371-384.

BARTON LL and FAUQUE GD (2009) Biochemistry, physiology and biotechnology of sulfate-reducing bacteria. Adv. Appl. Microbiol. 68 41-98. http://dx.doi.org/10.1016/S0065-2164(09)01202-7

BLANKENSHIP RE, OLSON JM and MILLER M (1995) Antenna complexes from green photosynthetic bacteria. In: Blankenship RE, Madigan MT snd Bauer CE (eds.) Anoxygenic Photosynthetic Bacteria. Springer, Houten, The Netherlands. 399-435.

BRUNE DC (1995) Isolation and characterization of sulphur globule proteins from Chromatium vinosum and Thiocapsa roseopersicina. Arch. Microbiol. 163 (6) 391-399. http://dx.doi.org/10.1007/ BF00272127

BURNS AS, PUGH CW, SEGID YT, BEHUM PT, LEFTICARIU L and BENDER KS (2012) Performance and microbial community dynamics of a sulfate-reducing bioreactor treating coal generated acid mine drainage. Biodegradation 2 (3) 415-429. http://dx.doi.org/10.1007/ s10532-011-9520-y

CHARACKLIS WG (1990) Biofilm processes. In: Characklis WG and Marshall KC (eds.) Biofilms. Wiley, New York.

COSTELLO C (2003) Acid Mine Drainage: Innovative Treatment Technologies. National Network of Environmental Management Studies, Washington DC.

COSTERTON JW, LEWANDOWSKI Z, CALDWELL DE, KORBER DR and LAPPIN-SCOTT HM (1995) Microbial biofilms. Ann. Rev. Microbiol. 49 711-757. http://dx.doi.org/10.1146/annurev. mi.49.100195.003431

DAVISON W, REYNOLDS CS, TIPPING E and NEEDHAM RF (1989) Reclamation of acid waters using sewage sludge. Environ. Pollut. 57 (3) 251-274. http://dx.doi.org/10.1016/0269-7491(89)90016-X
DENEF VJ, MUELLER, RS and BANFIELD JF (2010) AMD biofilms: using model communities to study microbial evolution and ecological complexity in nature. ISME J. 4 599-610. http://dx.doi. org/10.1038/ismej.2009.158

DRUSCHEL GK, BAKER BJ, GIHRING TM and BANFIELD JF (2004) Acid mine drainage biogeochemistry at Iron Mountain, California. Geochem. Trans. 5 13. http://dx.doi.org/10.1186/1467-4866-5-13

FIGUERAS JB, GARCIA-GIL LJ and ABELLA CA (1997) Phylogeny of the genus Chlorobium based on 16S rDNA sequence. FEMS Microbiol. Lett. 152 31-36. http://dx.doi. org/10.1111/j.1574-6968.1997.tb10405.x

FRIGAARD NU and DAHL C (2008) Sulfur metabolism in phototrophic sulfur bacteria. Adv. Microb. Physiol. 54 103-200. http://dx.doi. org/10.1016/S0065-2911(08)00002-7

GADGIL A (1998) Drinking water in developing countries. Ann. Rev. Energ. Environ. 23 (1) 253-286. http://dx.doi.org/10.1146/annurev. energy.23.1.253

GARCIA C, MORENO DA, BALLESTER A, BLAZQUEZ ML and GONZALEZ F (2001) Bioremediation of an industrial acid mine water by metal-tolerant sulphate-reducing bacteria. Miner. Eng. 14 (9) 997-1008. http://dx.doi.org/10.1016/S0892-6875(01)00107-8

GEREMIAS R, PEDROSA RC, BENASSI JC, FAVERE VT, STOLBERG J, MENEZES CTB and LARANJEIRA MCM (2003) Remediation of coal mining wastewaters using chitosan microspheres. Environ. Technol. 24 (12) 1509-1515. http://dx.doi. org/10.1080/09593330309385696

GREBEN HA, BOLOGO H and MAREE JP (2002) The effect of different parameters on the biological volumetric and specific sulphate removal rates. In: Biennial Conference of the Water Institute of Southern Africa (WISA), 19 - 23 May 2002, Durban.

HESHAM AEL, QI R and YANG M (2011) Comparison of bacterial community structures in two systems of a sewage treatment plant using PCR-DGGE analysis. J. Environ. Sci. 23 (12) 2049-2054. http:// dx.doi.org/10.1016/S1001-0742(10)60647-X

HIBBING ME, FUQUA C, PARSEK MR and PETERSON SB (2009) Bacterial competition: surviving and thriving in the microbial jungle. Nat. Rev. Microbiol. 8 (1) 15-25. http://dx.doi.org/10.1038/ nrmicro2259

HUGHES TA, GRAY NF and GUILLAMÓN OS (2013) Removal of metals and acidity from acid mine drainage using liquid and dried digested sewage sludge and cattle slurry. Mine Water Environ. 32 (2) 108-120. http://dx.doi.org/10.1007/s10230-013-0217-9

HURSE TJ and KELLER J (2004) Reconsidering the use of photosynthetic bacteria for removal of sulfide from wastewater. Biotechnol. Bioeng. 85 (1) 47-55. http://dx.doi.org/10.1002/bit.10816

HUSE SM, DETHLEFSEN L, HUBER JA, MARK WELCH D, RELMAN DA and SOGIN ML (2008) Exploring Microbial Diversity and Taxonomy Using SSU rRNA Hypervariable Tag Sequencing. PLoS Genet. 4 (12) http://dx.doi.org/10.1371/journal.pgen.1000255

JAMES GA, BEAUDETTE L and COSTERTON JW (1995) Interspecies bacterial interactions in biofilms. J. Ind. Microbiol. 15 257-302. http:// dx.doi.org/10.1007/BF01569978

JOHNSON DB and HALLBERG KB (2005) Acid mine drainage remediation options: a review. Sci. Total Environ. 338 3-14. http://dx.doi. org/10.1016/j.scitotenv.2004.09.002

KELLER J, OWENS CT, LAI JC and DEVAUD LL (2005) The effects of 17 beta-estradiol and ethanol on zinc- or manganese-induced toxicity in SK-N-SH cells. Neurochem. Int. 46 293-303. http://dx.doi. org/10.1016/j.neuint.2004.11.003

LAZAROVA V and MANEM J (1995) Biofilm characterization and activity analysis in water and wastewater treatment. Water Res. 29 (10) 2227-2245. http://dx.doi.org/10.1016/0043-1354(95)00054-O

LEE KY, KIM KW and KIM SO (2010) Geochemical and microbial effects on the mobilization of arsenic in mine tailing soils. Environ. Geochem. Hlth 32 31-44. http://dx.doi.org/10.1007/ s10653-009-9263-4

LEGALL J and FAUQUE G (1988) Dissimilatory reduction of sulphur compounds. In: Zehnder AJB (ed.) Biology of Anaerobic Microorganisms. Wiley, New York.

MADIGAN MT, MARTINKO JM, PARKER J and BROCK TD (1997) Microbial Ecology. Biology of Microorganisms. ( $8^{\text {th }}$ edn). Prentice Hall, Upper Saddle River, NJ. 
MALIK S, BEER M, MEGHARAJ M and NAIDU R (2008) The use of molecular techniques to characterize the microbial communities in contaminated soil and water. Environ. Int. 34 (2) 265-276. http:// dx.doi.org/10.1016/j.envint.2007.09.001

MARA D (2008) Waste stabilization ponds: a highly appropriate wastewater treatment technology for Mediterranean countries. In: Baz IA, Otterpohl R and Wendland C (eds.) Efficient Management of Wastewater. Springer, Berlin. http://dx.doi. org/10.1007/978-3-540-74492-4_10

MOHAMMED RA, MOHAMMED AA and HASSAN IH (2012) Characteristics of Raw Domestic Sewage for Basrah City. Basrah J. Eng. Sci. 12 (1) 60-71.

MOURA A, TACAO M, HENRIQUES I, DIAS J, FERREIRA P. and CORREIA A (2009) Characterization of bacterial diversity in two aerated lagoons of a wastewater treatment plant using PCR-DGGE analysis. Microbiol. Res. 164 (5) 560-569. http://dx.doi.org/10.1016/j. micres.2007.06.005

NAIRN RW, HEDIN RS and WATZLAF GR (1992) Generation of alkalinity in an anoxic limestone drain. Proc. 9th Annual National Meeting of the American Society for Surface Mining and Reclamation, Duluth, Minnesota.

NICOLELLA C, VAN LOOSDRECHT MCM and HEIJNEN JJ (2000) Wastewater treatment with particulate biofilm reactors. J. Biotechnol. 80 (1) 1-33. http://dx.doi.org/10.1016/S0168-1656(00)00229-7

OLEM H and UNZ RF (1977) Acid mine drainage treatment with rotating biological contactors. Biotechnol. Bioeng. 19 (10) 1475-1491. http://dx.doi.org/10.1002/bit.260191006

POINAPEN J (2012) Biological sulphate reduction of acid mine drainage using primary sewage sludge. International Mine Water Association, Annual Conference, 29 September - 4 October 2012, Bunbury.

POTT AS and DAHL C (1998) Sirohaem sulfite reductase and other proteins encoded by genes at the dsr locus of Chromatium vinosum are involved in the oxidation of intracellular sulphur. Microbiology 144 (7) 1881-1894. http://dx.doi.org/10.1099/00221287-144-7-1881

PRUDEN A, PEREYA LP, HIJBEL SR, INMAN LY, KASHANI N, REARDON K and REISMAN D (2006) Microbiology of sulfatereducing passive treatment systems. Proc. 7th ICARD, 26-30 March 2006, St. Louis, MO. ASMR Publishing, Taichun. http://dx.doi. org/10.21000/jasmr06021620

RENGER G (2008) Primary Processes of Photosynthesis: Principles and Apparatus. RSC Publishing London.

SAND W, GEHRKE T, JOZSA PG and SCHIPPERS A (2001) (Bio) chemistry of bacterial leaching - direct vs. indirect bioleaching. Hydrometallurgy 59 159-175. http://dx.doi.org/10.1016/ S0304-386X(00)00180-8

SCHLOSS PD, WESTCOTT SL, RYABIN T, HALL JR, HARTMANN M, HOLLISTER EB, LESNIEWSKI RA, OAKLEY BB, PARKS DH, ROBINSON CJ and co-authors (2009) Introducing mother: opensource, platform-independent, community-supported software for describing and comparing microbial communities. Appl. Environ. Microbiol. 75 7537-7541. http://dx.doi.org/10.1128/AEM.01541-09
SHENDURE J. and JI H (2008) Next-generation DNA sequencing. Nat. Biotechnol. 30 (10) 1135-1145. http://dx.doi.org/10.1038/nbt1486

SMUCKER NJ and VIS ML (2011) Acid mine drainage affects the development and function of epilithic biofilms in streams. J. N. Am. Benthol. Soc. 30 (3) 728-738. http://dx.doi.org/10.1899/10-139.1

STROSNIDER WH, WINFREY BK and NAIRN RW (2011a) Alkalinity generation in a novel multi-stage high-strength acid mine drainage and municipal wastewater passive co-treatment system. Mine Water Environ. 30 (1) 47-53. http://dx.doi.org/10.1007/s10230-010-0124-2

STROSNIDER WH, WINFREY BK and NAIRN RW (2011b) Biochemical oxygen demand and nutrient processing in a novel multi-stage raw municipal wastewater and acid mine drainage passive co-treatment system. Water Res. 45 (3) 1079-1086. http://dx.doi. org/10.1016/j.watres.2010.10.026

VALLE A, BAILEY M J, WHITELEY A S and MANEFIELD M (2004) $\mathrm{N}$-acylL-homoserine lactones (AHLs) affect microbial community composition and function in activated sludge. Environ. Microbiol. 6 (4) 424-433. http://dx.doi.org/10.1111/j.1462-2920.2004.00581.x

VAN DEN BERG MF, BOTES M, SLABBERT E and CLOETE TE (2016) The formulation of synthetic domestic wastewater sludge medium to study anaerobic biological treatment of acid mine drainage in the laboratory. Water SA 42 (2) 350-354. http://dx.doi.org/10.4314/wsa. v42i 2.18

VAN GEMERDEN H and MAS J (1995) Ecology of phototrophic sulfur bacteria. In: Blankenship RE, Madigan MT and Bauer CE (eds.) Anoxygenic Photosynthetic Bacteria. Springer, Netherlands. 49-85. http://dx.doi.org/10.1007/0-306-47954-0_4

VIEIRA BF, DO COUTO PT, SANCINETTI GP, KLEIN B and VAN ZYL D, RODRIQUEZ RP (2016). The effect of acidic $\mathrm{pH}$ and presence of metals as parameters in establishing a sulfidogenic process in anaerobic reactor. J. Environ. Sci. Health A Tox. Hazard Subst. Environ. Eng. 51 (10) 793-797. http://dx.doi.org/10.1080/10934529.2 016.1181433

WUERTZ S, BISHOP PL and WILDERER PA (2003) Biofilms in Wastewater Treatment: An Interdisciplinary Approach. IWA Publishing, London.

ZHU K, PAN H, LI J, YU-ZHANG K, ZHANG SD, ZHANG WY, ZHOU K, YE H, PAN Y, XIAO T and WU LF (2010) Isolation and characterization of a marine magnetotactic spirillum axenic culture QH-2 from an intertidal zone of the China Sea. Res. Microbiol. 161 (4) 276-283. http://dx.doi.org/10.1016/j.resmic.2010.02.003

ZHOU Q, CHEN Y, YANG M, LI W and DENG L (2013) Enhanced bioremediation of heavy metal from effluent by sulfate-reducing bacteria with copper-iron bimetallic particles support. Bioresour. Technol. 136 413-417. http://dx.doi.org/10.1016/j. biortech.2013.03.047 